\title{
Regulation of enterprise risk management: a comparative analysis of Australia, Germany and the USA
}

\section{Nicolai Bledow, Remmer Sassen* and Sylvia Ooi Sil Wei}

\author{
Department of Social Economics, \\ Faculty of Economics and Social Sciences, \\ University of Hamburg, \\ Rentzelstraße 7, 20146 Hamburg, Germany \\ Email: nicolai.bledow@gmail.com \\ Email: remmer.sassen@uni-hamburg.de \\ Email: sylwei86@gmail.com \\ *Corresponding author
}

\begin{abstract}
Enterprise risk management (ERM) has become a ubiquitous strategy, especially among international corporate governance regulations. This paper aims to examine the level of risk management regulation through an international comparison approach. Specifically, from a corporate governance perspective, we investigate the Australian risk management regulations and compare it to the regulations of the USA and Germany. We find clear differences in each country's approach, with the USA having the highest level of regulation, followed by Australia and finally Germany. This implies that the level of regulation depends on country-specific characteristics and that the strict regulations of the SOX have led to a high level of regulation. From a management perspective, it seems to be recommendable to harmonise the respective international regulations in order to provide multinational corporations with similar requirements across different countries. Accordingly, this paper proposes multilateral collaboration in harmonizing international ERM regulations in order to avoid that firms take unnecessary risks. As a consequence, this harmonization stabilizes in turn the global financial system.
\end{abstract}

Keywords: risk management regulations; corporate governance; enterprise risk management; ERM; COSO framework; international comparison; Australia; Germany; USA.

Reference to this paper should be made as follows: Bledow, N., Sassen, R. and Wei, S.O.S. (2019) 'Regulation of enterprise risk management: a comparative analysis of Australia, Germany and the USA', Int. J. Comparative Management, Vol. 2, No. 2, pp.96-122.

Biographical notes: Nicolai Bledow is finance professional with experience in investment banking, financial due-diligence and controlling. He is currently working as an Assistant to the Management of Aqseptence Group. He is a former bachelor student of the Justus Liebig University of Giessen, a former master student of the University of Hamburg and a visiting scholar of the Macquarie University in Sydney. 


\begin{abstract}
Remmer Sassen is a Senior Researcher at the University of Hamburg. Since November 2016, he manages the HOCH-N action field sustainability reporting in collaboration with Freie Universität Berlin and Universität Duisburg-Essen. Furthermore, he has managed several (international) projects on sustainability reporting and management of firms and universities. His research topics are primarily related to external reporting of firms and universities (e.g., sustainability reporting, integrated reporting risk reporting, corporate governance reporting, etc.).
\end{abstract}

Sylvia Ooi Sil Wei is currently a master student at the Hamburg Universität. She is interested in the field of sustainable development and corporate governance.

\title{
1 Introduction
}

Enterprise risk management (ERM) has gained rising importance for tackling the difficulties of preparing for the unexpected (Majone, 2010). Furthermore, the recent less stringent regulatory regime regarding corporate governance and reporting as currently seen in the US under the Trump/Pence era calls for a focus on establishing risk management systems when managing and mitigating risk (Narine Weldon, 2017). In Australia, the widespread risk management failures at banks might lead to an economic downturn (Kehoe, 2018). As a response to a series of financial disasters in the early 2000s, globalisation and legislative coercion to regulate firm risks comprehensively, ERM has received growing interest among regulators, rating agencies, academics and practitioners over the last decade. In addition, the turmoil in the capital markets has led to global government cooperation to end 'the age of irresponsibility' so that ERM is a prominent conception in academic research and business practice (Bromiley et al., 2015). Hence, regulators, auditors, shareholders, authorities, board executives and risk assessment agencies opted for more holistic risk management systems in an attempt to decrease the amount and severity of events and to regain the investors' trust in the financial markets (Happ and Pott, 2007). Thus, ERM has become a ubiquitous strategy of governments, especially among international corporate governance regulations and policies (Power, 2004b; Nölke, 2010). In the wake of the global financial crisis, this has caused public and academic debates on the need for increased regulation and its effective execution (Duffie, 2017; Larsson and Söderberg, 2017). Since then there have been drastic changes in the structure of regulation. For instance, the US Congress adopted the Consumer Protection Act of 2010 and the Dodd-Frank Act with the objective of systemic risk mitigation towards a better regulatory system (Omarova, 2015). In Australia, the Public Governance, Performance and Accountability Act (PGPAA) 2013 outlines the details of the Australia Council's risk management obligations (Highley, 2016).

The current empirical literature has scarcely addressed core practitioner concepts. According to Bromiley et al. (2015), a critical review of ERM regulation across countries allows us to identify limitations and challenges in ERM research and practice and promises interesting results for theory and practice. The ERM field still remains to be challenging regarding the development of proper frameworks for this matter (SRA, 2015). Under the lens of management, ERM comparison among countries can help to resolve these challenges by showing the effectiveness of corporate governance structures 
and the level of the risk management implementation requirements (Kleffner et al., 2003; Fraser et al., 2010). Additionally, research on ERM is often too narrow so far and focuses only on the micro dimension of ERM development (Barton et al., 2002). Therefore, research did not take into account the more macro-economic level of risk management. Against this background, our study aims to address two gaps in contemporary literature. First, there are quite different approaches to regulate ERM which range between a high degree of freedom and a high degree of regulation. Nevertheless, it is unclear which ERM regulations approach promises the greatest success. Second, the theoretical foundation of ERM regulation is often ignored, although the significant influence of regulation is widely acknowledged. The most common argument supporting the need for regulation is derived from the core problem of multiple principal-agent relationships (Jensen and Meckling, 1976) while theories of regulation take into account different approaches on how interest groups behave and intervene in the regulatory process based on assumptions concerning their power, motivation and assertiveness. The overall objective of the theories related to regulation is to make assumptions on the extent of regulatory provisions, and how these should be implemented. Taking one step backwards, the understanding of the conceptual root of regulation allows a holistic approach to rethinking the management model of ERM and political uncertainty (Power, 2004a; Ndedi and Kingsly, 2015).

In view of the conventional debate on cross-national patterns, corporate governance is converging as a result of internationalisation (Yoshikawa and Rasheed, 2009). Many academics debated about the transferability of good practices on the prospect of international convergence despite the wide variation in corporate governance practices around the world (Yoshikawa and Rasheed, 2009; Khanna et al., 2006). In this regard, other systems view the US (and the Anglo-Saxon) corporate governance system as a benchmark that can be useful for comparison (Warin and Sanger, 2018). Despite the continuous burgeoning interest in ERM, Power (2004a) proposed to rethink the development of ERM in order to avoid ERM being interpreted as another fashionable latest management fad. Thus, our research focuses on examining the level of risk management regulations through an international comparison approach to identify the appropriate level of ERM regulation.

We examine the differences of ERM regulations between Australia, Germany and the US in order to broaden the knowledge on ERM regulation approaches. From a methodological standpoint, this paper conducts an international comparison approach with a focus on country-specific regulations in order to make recommendations relevant to the development of future ERM regulations. In particular, we compare the risk management regulations of Australia to those of the US and Germany respectively, which were reviewed in a previous study by Sassen (2014). To expand the understanding of ERM regulations and its consequences for ERM, we provide a comparative analysis by taking a management-oriented corporate governance perspective and a comparative analysis is able to identify the differences in systems. We chose Australia because of its significant changes and enhancements within structural risk management process approach [Australian New Zealand Risk Management Standard (AS/NZS ISO 31000: 2018]. Since November 2009, the AS/NZS ISO 31000: 2009 have been superseded by the previous Australian and New Zealand risk management standard AS/NZS 4360: 2004 (AS ISO 31000, 2009). More recently, the first edition (ISO 31000:2009) has been technically revised replaced by the second edition. The main changes of the revised edition outlined have no substantial impact on this study. In view of the differences of 
regulations among countries, we can make comparison between AS/NZS ISO 31000:2018 (hereinafter referred to as AS/NZS ISO 31000:2018) and COSO I and II. Additionally, the recent widespread risk management failures at Australian banks motivate the interests of academics in the ERM field to further study the risk management regulations in Australia (Kehoe, 2018). The comparative analysis between multiple (categories) cases whose primary purpose is to enhance explanatory understanding for the causal processes (Pickvance, 2005). For the comparative approach, we considered two more countries (Germany and the USA) which are suitable for our data analysis and discussion. Increasing the variation in the explanatory variables further construct an in-depth effective comparison (Pickvance, 2005). For the comparison to the mentioned countries, Australia is a distinct case since its regulation approach is generally similar to that of the US (common-law system) but some of its regulatory instruments are similar to that of Germany (civil-law system) [e.g., if not why not-approach of the Corporate Governance Principles and Recommendations (CGPR)].

This paper does not only identify how management scholars can contribute to ERM research, but also indicates why ERM research and practice needs management research for its development. The results can support other countries to absorb, learn and integrate effective ERM regulations based on their respective national economic, social, legal and political characteristics.

The remainder of this research is organised as follows. Section 2 outlines the research framework including a conceptualisation of ERM, a theoretical background focusing on theories of regulation and a literature review that provides an overview of international risk management research. The methodology section (Section 3) includes information on the international comparison procedure and the scoring model to benchmark and determine the value of the regulations. Moving on to the comparison of international policies, Section 4 evaluates the fundamentals of the Australian risk management regulations. Section 5 discusses the results by comparing the scores of Australia to that of the US and Germany, highlighting the influence of country-specific factors on the respective regulatory level, and provides recommendations on future regulations. Finally, an overall conclusion is drawn in the final section (Section 6).

\section{Research background}

\subsection{Conceptualisation of enterprise risk management}

Before establishing a review of international risk management research, it is essential to understand the meaning of ERM and the origin of ERM regulation. Despite a wide range of definitions that have been developed since the $1960 \mathrm{~s}$, there is still a lack of a coherent and precise definition of ERM in the literature (Haji-Togok et al., 2014). According to the Casualty Actuarial Society (CAS, 2003), ERM is "the process by which organizations in all industries assess, control, exploit, finance and monitor risks from all sources for the purpose of increasing the organization's short and long-term value to its stakeholders." Given the wide variety of definitions and implementations of ERM, the term ERM covers a broad concept (e.g., COSO, 2004) and can be defined as a 'umbrella concept' (Mikes, 2009). Bromiley et al. (2015) specified the scope and categorised the ERM meaning largely into several distinct groups, for example, risk is viewed as largely defined threats to be mitigated, achievements of organisational goals and potential catalyst for value 
creation. In general, understanding the conceptual roots may clarify the ambiguity surrounding ERM. COSO (2004) defines ERM as "a process, effected by an entity's board of directors, management and other personnel, applied in strategy setting and across the enterprise, designed to identify potential events that may affect the entity, and manage risk to be within its risk appetite, to provide reasonable assurance regarding the achievement of the entity objectives." In other words, risk management can be referred to as the intent to assure that the management is able to effectively respond to conditions that can have an adverse effect on the organisation. Additionally, there are other risk management terms with several different foci such as corporate risk management, business risk management, holistic risk management, strategic risk management and integrated risk management (D'Arcy and Brogan, 2001). The same is true for risk measurement (accounting-based and market-based risk measures) (Sassen et al., 2016). Furthermore, risk in its economic sense and the management of risk does not come without a clear impact on general business and accounting processes (Power, 2004b).

Moreover, the origin of ERM regulations are summarised as follows. In the 1995 Australian/New Zealand Standard for Risk Management, an entity wide approach was considered by regulators for the first time. Following the implementation of the German Corporate Control and Transparency Act (KonTraG) in 1998, and the 2002 Sarbanes-Oxley Act (SOX) in the USA, risk management became a substantial and partly legally required task for an increased number of firms. Furthermore, the Committee of Sponsoring Organizations (COSO) of the Treadway Commission's has published the ERM framework in 2004 (COSO, 2004). Following COSO's 1992 framework on internal control (COSO I), the ERM framework is also known as COSO II (COSO, 1992, 2004). COSO framework was updated in 2017 as 'Enterprise risk management - integrating with strategy and performance' to consider the importance of risk in both the driving performance and strategy-setting process (COSO, 2017). The COSO framework is currently seen as the most important guideline in ERM (Power 2004b; Desender and Lafuente 2012; Paape and Speklé, 2012).

Today's risk management focuses on a much wider array of risks such as financial, operational, reputational, and regulatory risks (Nocco and Stulz, 2006; Simmons, 2013; Arena et al., 2010). This rather holistic view aims to aggregate all different risks a firm faces and to manage them from a centralised management-level perspective (Nocco and Stulz, 2006; Sassen 2014). This approach to ERM is also referred to as corporate, integrated, holistic, enterprise-wide, or strategic risk management (Kraus and Lehner 2012; Nocco and Stulz, 2006). For the reason of consistency, this research will be limited to the expressions risk management and ERM, which are used synonymously throughout this research.

\subsection{Theoretical background: theories of regulation}

The regulatory background of ERM, its implications and consequences are rarely considered in the previous literature. Although the significant influence of regulation may be common sense, its theoretical foundation is generally not taken into account and shall therefore be explained throughout the following by using theories of regulation. Each theory of regulation considers a different approach on how interest groups will behave and intervene in the regulatory process based on different assumptions concerning their power, motivation and assertiveness. The complementary theories are generally categorised into: 
1 normative

2 positive approaches (Freidank and Sassen, 2012; Nguyen and Molinari, 2009).

Normative theories refer to the circumstances and reasons that lead to regulation with the assumption that the regulators aim to increase economic welfare while positive theories explain the observable behaviour of regulators, the regulated and other interest groups, without concern on welfare effects.

1 The normative free market theory assumes that regulation will only restrict the available set of contracts between two or more parties (Hart, 2009). Hence, regulation will only hinder the market and lead to inefficiencies (Nguyen and Molinari, 2009). Regulatory interventions are generally not required, as market competition will bring about appropriate incentives (Booth, 1997), and economic efficiency (Shleifer and Vishny, 1997; Booth, 1997). This implies that competition forced companies to adopt corporate governance mechanisms, in order to minimise costs (Shleifer and Vishny, 1997). However, the problems with this theory lie within its assumptions since perfect market assumptions, such as perfect distribution of information, or more generally the optimal allocation of resources, are not met in practice (Booth, 1997; Hertog, 2010). Markets tend to fail due to, inter alia, monopoly, asymmetric information, externalities, the production of public goods, or bounded rationality (Shleifer, 2010; Majone, 1994; Coglianese and Lazer, 2003; Hertog, 2010). Overall, missing its practical link this approach can easily be encountered by the evidence of market failures (Posner, 1974), constituting a need for regulatory intervention (Coglianese and Lazer, 2003).

Within the public interest theory, regulation is seen as a legitimate answer to market failure (Posner, 1974). More precisely, where public benefits exceed the costs of those being regulated, regulation will be claimed (Nguyen and Molinari, 2009). It can oppose market imperfections by reallocating resources, and accordingly increase efficiency, and social welfare (Posner, 1974; Shleifer, 2005; Hertog, 2010). Especially asymmetric information plays an important role. Risk management regulation can contribute to a better allocation of information and may therefore, decrease the effects of adverse selection and reduce the problem of moral hazard (Nguyen and Molinari, 2009; Hertog, 2010). A central assumption of the theory is that regulators behave altruistic and act in the interest of the public (Stigler, 1971; Posner, 1974). Individual interests, capabilities, the availability of the regulators' resources and the proof of a linkage between the public interest and the resulting legislative action are ignored (Stigler, 1971; Posner, 1974; Shleifer, 2005; Nguyen and Molinari, 2009). Hence, it is criticised that regulatory intervention is automatically expected to be efficient and increase economic welfare (Nguyen and Molinari, 2009; Hertog, 2010). This argument could then be used as an argument for an overly excessive use of regulation. Counterarguments also refer to regulatory actions which cannot be explained by market failures or under welfare increasing aspects (Stigler, 1971; Posner, 1974; Nguyen and Molinari, 2009). Further, mechanisms of market forces and private litigation, which will provide efficient solutions to most of the possible failures, are not taken into account (Shleifer, 2005; Hertog, 2010). Even if there are no contracts, impartial courts and tort rules will be more efficient than regulation (Shleifer, 2005). Adding transaction costs to the 
theory, market outcome will still be efficient and thus, does not give reason for regulation (Hertog, 2010). Despite its criticism, this theory provides a fundamental insight into the rationales of regulation.

2 Positive approaches focus on the way how regulation emerges and thus take a rather procedural perspective in their analysis (Posner, 1974). The capture theory picks up the criticism of the public interest theory on the missing link between regulators and the regulated and establishes a hypothesis based on the conflicting interests of these parties. The term capture refers to the attempt of the regulated party to eventually, gain control over the bureaucrats and thus influence regulatory policy. Practically, this means that the companies or industries which fall under a certain regulation will try to shift agencies' and politician's interests, in order to gradually alter their policies and achieve a more desirable result of intervention (Nguyen and Molinari, 2009; Hertog, 2010). Certain assumptions concerning the behaviour of the regulators are critical to the theory, such as their interests assumed to be possible future job opportunities with the regulated branch, internal budget concerns, or simply avoiding litigation costs (Nguyen and Molinari, 2009; Hertog, 2010). As these interests may not be compliant to outside expectations, the bureaucrats may search for excuses to hide their original motivations (Nguyen and Molinari, 2009). To draw a parallel to ERM research, this could mean, that existing policies are at least partly brought in place in favour of hidden interests, such as political reputation, its effects on market competition, and so on (Power, 2004b).

Based on the capture theory, the economic theory of regulation challenges the basic assumption of the origin of regulation and instead views regulation as a product, being subject to the rules of supply and demand (Stigler, 1971; Posner, 1974). By applying these assumptions, this approach still allows for a capture situation but extends the theory to other politically active groups (Posner, 1974). Driven by the private interest of these groups, the rules of supply and demand assure that regulation is supplied to the group which will pay the highest price, while each group will act rationally and utility maximising (Posner, 1974; Nguyen and Molinari, 2009). Implemented regulation does not necessarily lead to an increase in the overall welfare (Nguyen and Molinari, 2009). Also, regulators are not expected to be perfectly informed and will thus value additional relevant information from outside (Nguyen and Molinari, 2009). The utility of politicians, in the sense of being the regulators, is defined by votes and money. Accordingly, the overall welfare only matters indirectly through its effect on the fundamental power and size of the system that a politician may profit from (Peltzman et al., 1989). Concluding these assumptions, specifically business regulation will be expected to be in favour of large organisations (firms, industrial associations, etc.) as they have the highest interest in the outcome of business regulation, aggregate the most information, money, and power while also being well organised (Peltzman, 1976; Peltzman et al., 1989; Nguyen and Molinari, 2009). Similarly, practical examples of health, safety, and environmental policy can be held against this theory and support the approaches of the public interest theory and the capture theory (Peltzman et al., 1989). This means that regulation favours different groups (consumers, employees, etc.) and it is not exclusively favourable to the industry (Hertog, 2010). Transferring these results to the ERM context will mean that specifics, such as the internal diffusion of interest groups, industry peculiarities, and general economic settings, will have to be 
considered in order to find an optimal level of regulation. The generality and strong simplification of the theoretical approach makes it difficult to apply the theory to practical issues and is crucial to its criticism (Peltzman et al., 1989). The missing delineation and evaluation of the interactions and relationships between politicians and agencies, but also between shareholders, employees, consumers, other activist, and the companies, leave little room to conclude on the efficiency of regulation which addresses particular and individual issues (Hertog, 2010). Furthermore, the question to why regulation has become a ubiquitous tool to modern economic systems cannot be answered conclusively (Shleifer, 2005).

\subsection{Overview of international enterprise risk management research}

ERM research has received growing attention throughout the last decade, leading to an increase in the number of related publications (Choi et al., 2015). This literature review of international ERM research focuses on studies investigating factors (motivations) that determine the degree of ERM implementation, the impact of ERM on firm value and the analysis of ERM regulatory frameworks.

1 A central topic to ERM research lies within the factors associated with its implementation and adoption of firm risk management activities. Many studies only rely on the past announcements of a chief risk officer (CRO) as a proxy for ERM implementation. This problem was rooted in the absence of publicly available information on the indicators of ERM adoption within the companies (Hoyt and Liebenberg, 2003; Pagach and Warr, 2011; Eckles et al., 2014). Typical approaches to overcome this limitation use an increased number of indicators within the SEC requirements of public disclosures (Hoyt and Liebenberg, 2011), or by analysing survey results (e.g., the Risk Maturity Model by the Risk and Insurance Management Society) (Paape and Speklé, 2012; Farrell and Gallagher, 2015). The factors commonly expected to have an impact on the companies' decision to adopt ERM include or relate to firm size, firm- and industry-related characteristics, internal influences, revenue growth, ownership structure and corporate governance practices such as the independence of the board (e.g., Khan et al., 2016; Pagach and Warr, 2010; Hoyt and Liebenberg, 2011; Paape and Speklé, 2012). The presence of CRO, firm size, international diversification and the industry sector (banking, insurance, energy) are drivers to implement ERM (e.g., Lechner and Gatzert, 2018; Farrell and Gallagher, 2015; Beasley et al., 2008). Most of the results are consistent (Paape and Speklé, 2012) and show that size, the presence of a CRO, an audit committee, as well as belonging to the financial industry, have a positive effect on the degree of ERM implementation.

2 A method frequently used to analyse the impact of ERM on valuation is the Tobin's Q ratio (Lechner and Gatzert, 2018; Farrell and Gallagher, 2015; Grace et al., 2015; Hoyt and Liebenberg, 2011). Bohnert et al. (2019) confirms high-quality risk management programs lead to increasing the shareholder value of firms which is in line with previous studies (i.e., Hoyt and Liebenberg, 2006, 2011; Baxter et al., 2013; Farrell and Gallagher, 2015; Ai et al., 2016; Lechner and Gatzert, 2018). Baxter et al. (2013) additionally calculate the abnormal returns around the announcement of ERM quality ratings. The study of Grace et al. (2015), on the other 
hand, avails a different approach by applying efficiency measures in a value-added approach. Partly contradicting to the mixed results of earlier research (Beasley et al., 2008; McShane et al., 2011; Kraus and Lehner, 2012), further studies illustrate a positive impact of ERM on the companies' valuations (Baxter et al., 2013; Farrell and Gallagher, 2015; Grace et al., 2015; Hoyt and Liebenberg, 2011). Farrell and Gallagher (2015) and Grace et al. (2015) determine the impact of specific ERM components and highlight the importance of executive engagement and ERM reporting to the board of directors. Other criteria found to be significantly relevant to value creation include the effective integration of the ERM process into daily operations, the alignment of ERM and the firm's strategy (Farrell and Gallagher, 2015), along with the presence of dedicated internal risk management entities such as committees or a risk manager (Grace et al., 2015). Moreover, Shanmuganathan (2018) reviews the corporate governance relationship with strategic management and analyses whether the corporate governance influences on strategic management decisions. Farrell and Gallagher (2015) find that the concept of risk appetite management, derived from the COSO ERM framework (COSO, 2004), together with the companies' general resilience and sustainability show insignificant impact on the valuation of a firm.

3 Turning to regulatory framework and policy analyses, McShane (2018) recommends a design science approach for organisational ERM implementation. Hayne and Free (2014) review the origin, conceptualisation, and distribution of the COSO ERM framework. The study builds upon interviews with the entities involved in the creation and dissemination of the framework in order to refer to the critical attributes of the framework as an innovation (Hayne and Free, 2014). In contrast, Paape and Speklé (2012), and Tekathen and Dechow (2013) compare and evaluate the use of the COSO framework by its practical implications and effectiveness. As to that, Paape and Speklé (2012) perform a survey analysis with questions relating to specifications of the COSO framework, while Tekathen and Dechow (2013) apply a case study by putting the abstract of the COSO concept in direct comparison to an example of practical experience from a large German corporation (Tekathen and Dechow, 2013). In line with prior literature (Bromiley et al., 2015; Demidenko and McNutt, 2010; Farrell and Gallagher, 2015), an aspect central to the criticism of the COSO framework is the open-ended design, or in other words, the lack of precise instructions and specifications of the framework (Dornberger et al., 2014; Paape and Speklé, 2012; Tekathen and Dechow, 2013). As COSO is considered as a challenging perspective, Dias (2017) argued that ISO 31000:2009 is an alternative to COSO ERM 2017 for a more effective audit. Furthermore, general assumptions such as the ability to quantify and calculate risk tolerance and risk appetite, are claimed infeasible in reality (Paape and Speklé, 2012; Tekathen and Dechow, 2013). Furthermore, Paape and Speklé (2012) observe that the framework is not perceived as effective, while at the same time they reflect on the difficulties of setting a standard without the presence of sufficient theoretical and empirical background when the framework was created (Paape and Speklé, 2012). Sassen (2014) compares the risk management regulations of the US to the regulations of Germany and finds that the overall level of risk management regulation is significantly higher in the US than in Germany. 
In summary, the central topics of ERM research mainly focus on the overview of the internal perspective, in particular, the micro-level firm businesses analysis. International comparison studies remain rather limited within the management field (Bromiley et al., 2015). Recent ERM literature mainly focuses on technical aspects of risk management theories and practices but is lacking detail in wider settings and context (social, institutional and organisational), especially from a comparative point of view on an international level. To divert from the central topics of ERM research, this paper sets out to critically evaluate the macro-level ERM legislations between countries.

\section{Methodology}

To approach the research objective and to extract and determine the level of regulation, we use the international comparison approach and benchmarking by a scoring model following the study by Sassen (2014) which proposes an interdisciplinary research domain for management scholars. By using an international comparison approach, the mentioned study compares risk management regulation from a corporate governance perspective of listed stock corporations in Germany and the USA by applying a scoring model to measure the extent of regulation with a numeric measure [see Table 1 in chapter 5; for details see Sassen (2014)]. Several characteristics define the comparative analysis approach. One of the common features is to provide explanations why such similarities and differences exist. Another is related to the dependence on the data collection on multiple cases, ideally in accordance to common frameworks (Pickvance, 2005). The rationale of comparative law research is the improvement of domestic legal doctrine. Therefore, it can be used to make recommendations for harmonisation between the investigated legal systems. However, a contextual approach is important for transferring legal systems from other nations. According to Glenn (2006), comparative law aims at:

a harmonising of law

b learning, knowledge and application according to various contextual approaches

c becoming the instrument of evolutionary and taxonomic science.

The methodologies for international comparison are similar to some of the methodologies adopted in the literature on country risk assessment. The common non-objective techniques are scoring models which aggregate index data on various risk variables (Dahringer and Mühlbacher, 1991; Müller-Berghoff, 1984), experts' perceptions and evaluations, analytical hierarchy process (AHP) (Kayastha et al., 2013), and other various statistical methods, such as regression and factor analyses (Levy and Yoon, 2001).

This paper uses an additive scoring model which follows the basic steps of a multi-attribute utility analysis frequently found within economical, business, medical, and other decision problems (Huber, 1974; Keeney and Raiffa, 1993; Zangemeister, 2014). Central to the method stands the problem of quantifying qualitative data (Zangemeister, 2014), such as, in the case of this study, the transition of the level of regulation into a numerical value. In such cases, the value does not represent a utility value but the level of regulation. The value is needed not only to allow for a more systematic comparison but for an overall evaluation of the individual standard of regulation in relation to the 
possible maximum and minimum extent (Zangemeister, 2014). Despite the fact that the method of multi-attribute utility analysis is based on subjective evaluations, it represents a systematic approach following a predefined and structured process with three steps (Sassen, 2014; Zangemeister, 2014). In the first step the target criteria, also known as the attributes, have to be defined (Keeney and Raiffa, 1993). In the given case, we defined the criteria similar to Sassen (2014) since consistent data supports a better comparison. These are the:

1 level of regulation of ERM implementation

2 the ERM process

3 the consideration of ERM within the accounting

4 the consideration of ERM in reporting

5 the consideration of ERM in the external corporate monitoring system.

In a second step, each of the mentioned criteria is allocated with a subjective weight depending on its overall relevance (Keeney and Raiffa, 1993). Following Sassen (2014), in the case of the (1) implementation and (2) process requirements, the maximal weights are set to 5.0 points each because these are the core aspects of ERM. The more supportive (4) consideration of ERM in reporting is maximally weighted at 2.0 points, while the consideration of ERM in (3) accounting and in (5) the external monitoring system are maximally weighted at 1.0 point each. 14.0 points are achievable in sum. The third step entails the determination and quantification of the 'partial utility values' or the partial scores (Zangemeister, 2014). In the given case, the partial scores are dependent on the degree to which the respective requirements have a mandatory (full number of points in each of the five categories) or voluntary (half number of points in each of the five categories) character. In order to ensure the reliability and consistency of the findings, all authors have been involved in the scoring process. In case of different scores among the authors, we discussed them and came to unanimously results.

While determining the level of Australian ERM regulation, it is necessary to apply the same approach used for Germany and the US to create comparable scoring results. Therefore, the next chapter begins with an analysis of the background of the Australian corporate law and corporate governance structures. Finally, we determine the specific regulatory requirements related to the five mentioned areas. To generate a high scoring transparency, we explain at the end of each chapter the reasons for our scoring.

\section{Evaluation of Australian risk management regulation}

\subsection{Background of the Australian corporate law and corporate governance structures}

Similar to the US law, Australian law is based on the common law system, featuring a strong judicial focus on precedents (previous cases) and on the court's fiduciary duties (La Porta et al., 2000). Corporate law particularly shows a strong historical influence of the legislature of the UK, with increasing specifications and individual amendments only throughout the last century (Nessen, 1999). A temporary solution of building corporate 
law on the basis of state law, to a degree similar to the current US system, ultimately became replaced by a Commonwealth approach (Nessen, 1999).

Figure 1 Institutional structure governing Australian non-financial stock corporations

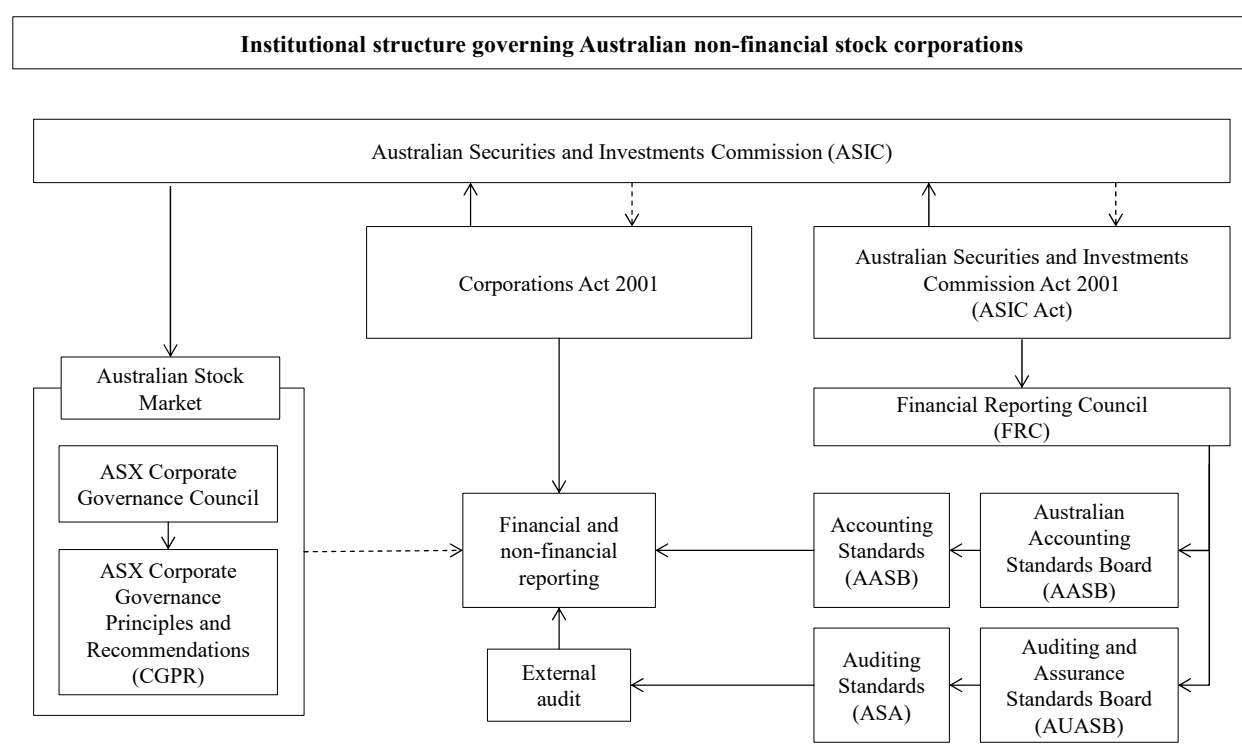

Today, the Corporations Act 2001 (CA) stands central to the Australian wide business policy (Tomasic, 2006). Parallel to the CA, the Australian Securities and Investments Commission Act 2001 (ASIC Act) became implemented (Section 2 of the ASIC Act). Both laws are administered and enforced by the Australian Securities and Investments Commission (ASIC) (see Figure 1) [Section 5B of the CA; Section 11(1), (6) of the ASIC Act; Section 1 of the ASIC Act]. The CA provides the basic provisions for the general conduct of business, determining entity types (Section 112 of the CA), the rules for corporate governance structures and director's duties (Part 2D.1 and 2D.3 of the CA), as well as setting the basic reporting and auditing requirements (Section 285 of the CA). The ASIC Act, on the other hand, represents the legal foundation for the institutions concerned with financial reporting and auditing and related standards (Section 261 of the ASIC Act; Section 225 and 227 of the ASIC Act; Section 227A of the ASIC Act). Besides determining the work of the ASIC itself (Part 2 Division 1 of the ASIC Act; Part 4 to 6 of the ASIC Act), the ASIC Act constitutes the rights of the Financial Reporting Council (FRC) as an oversight body for the standard setters (Section 225 of the ASIC Act). The standard setters are then represented by the Australian Accounting Standards Board (AASB), in charge of the development of accounting standards (Section 227 of the ASIC Act), and the Auditing and Assurance Standards Board (AUASB), in charge for the development of the respective auditing standards (Section 227B of the ASIC Act). Other than that, according to Section 798F of the CA in conjunction with Section 795B (1) of the CA, the ASIC also supervises the Australian financial markets and its operators such as the Australian Securities Exchange (ASX). The ASX's Corporate Governance Council is, in turn, the publisher of the CGPR. 
Furthermore, there are additional regulatory bodies for the oversight of specific industries, sectors, and transactions which are not taken into account within this research.

Figure 1 shows an overview of the institutional structure governing Australian non-financial stock corporations. In summary, risk management in Australia is implicitly regulated by law (Sections 180 and 181 of the CA) and quasi-legally regulated by the ASX requirements in conjunction with relevant frameworks.

Looking into the details of business regulation, publicly listed companies may include companies limited by shares, limited by guarantee, unlimited with share capital, and no liability companies [Section 122(1) of the CA]. Besides crucial consequences on the liability in case of liquidation (Section 514 to 519 of the CA), main differences between these types of companies are for example made with regards to reporting requirements [Section 285(1) of the CA; Section 300(10), (11) of the CA]. The exact differences are not of further concern since this study focuses only on the regulations for companies limited by shares (Section 516 of the CA).

Regarding the internal management structure and its setup, initially it has to be noted that a company has the option between the compliance to certain replaceable rules of the CA, or rules set by its own constitution, or a combination of those (Section 134 to 136 of the CA; Section 141 of the CA). One such replaceable rule includes the appointment of directors (Section 201G of the CA) who are otherwise generally elected by the shareholders at the annual general meeting (AGM) [Section 250R(1)(b) of the CA; Part 2G.2, Division 2 of the CA]. Similar to the US, the board of directors may consist of executive and non-executive directors, including independent directors (Kang et al., 2007). With regards to the board's composition, the CGPR further recommends the majority of directors to be independent (CGPR, Rec. 2.4), including the chairman of the board, who in particular should not be represented by the chief executive officer of the company (CGPR, Rec. 2.5). Similar to the US and Germany, the board may elect committees out of the group of its members and delegate tasks to these committees [Section 198D(1)(a) of the CA]. The CGPR builds upon this option by suggesting a number of different committees, including a nomination committee, which is in charge of the process of the appointment of directors (CGPR, Rec. 2.1). Relevant to this is Section $201 \mathrm{H}$ (3) of the CA, under which directors may also be appointed by other directors. In that case, however, the appointment has to be confirmed by the next AGM (Section 201E of the CA). For public companies, these AGMs are to be held within five months after the end of their fiscal year [Section 250N (2) of the CA]. Other functions of the AGM include the consideration of the financial report, the director's report, and the auditor's report [Section 250R(1)(a) of the CA], as well as the appointment of the external auditor [Section 250R(1)(c) of the CA].

In Australia, public companies further have to have a secretary [Section 204A(2) of the CA]. The secretary is appointed by the directors (Section 204D of the CA). The duties of the secretary are mostly of administrative nature and are defined in Section 188(1) of the CA. They include tasks related to the communication, information exchange, and lodgment of documents with the ASIC [Section 188(1) of the CA; Section 254X of the CA]. According to the CGPR's Rec. 2.4, the secretary should not only report to the board but also monitor and advise the board on governance issues and procedures. Apart from these requirements, the Australian corporate governance system is structured in a relatively similar way to the unitary system of the US corporations, showing a similar flexibility in terms of the allocation of supervisory tasks as opposed to management tasks. 


\subsection{ERM implementation and process}

Besides the described regulations on the corporate governance structures and the resulting allocation of tasks among the group of directors and the secretary, neither the ASIC Act nor the CA indicate or assign a direct risk management duty to any of the companies' organs or institutions. By hard law, the engagement in a risk management system is only required for financial services companies that fall under Section $912 \mathrm{~A}(1)(\mathrm{h})$ of the CA. Nonetheless, it can be argued, that the central duties of directors and other officers entail the consideration of any kind of risk and its management in all of the directors' positions and decisions, as the director's duties are stated by the law to be exercised with care and diligence, and in the best interest of the company (Section 180 and 181 of the CA; Lowry, 2012).

Left aside the interpretive assumptions on the practical meaning of these words, the ASX has a central and partly monopolistic stance within the Australian stock market (Heathcote, 2003). Therefore, its listing rules and the subsequent principles and guidelines can clearly be said to be of significant importance for any company listed in Australia. Within the ASX's CGPR, risk management requirements are mentioned multiple times and are formulated with clear distinction throughout Principle 7. This principle advises a listed company to 'recognise and manage risk' (p.28) by establishing and periodically reviewing a risk management framework. The subsidiary Rec. 7.1(a) suggests the appointment of a risk committee, which may be represented by a combined audit and risk committee as well. The committee should consist of a majority of independent directors and be chaired by an independent director. It should be of sufficient size, have the appropriate knowledge, and an adequate understanding of the industry (CGPR, Rec. 7.1, Commentary). It should further review the established framework annually and disclose on that review (CGPR, Rec. 7.2).

Other than that, within Principal 7, the ASX also makes a statement on the choice of risk management frameworks perceived as appropriate (CGPR, Principle 7, Commentary, footnote 35). Besides referring to the COSO ERM framework too, the Australian/New Zealand Standard AS/NZS ISO 31000:2018 is mentioned. In comparison to the COSO framework, the ERM procedure described by the AS/NZS framework includes familiar steps such as context establishment, risk identification, risk analysis, risk evaluation, risk treatment, communication and consultation, and monitoring and review (Demidenko and McNutt, 2010; Purdy, 2010). Overall, despite the fact that these guidelines are soft law, with respect to the ASX's market dominance, the provisions constitute a rather precise picture of the stock market's expectations in terms of structural and procedural adjustments.

Overall, risk management primarily is set as a task by the ASX regulations (CGPR Rec. 7) which are implicitly mandatory for public companies. Thus, given the Australian corporate governance system, the benchmark scoring analysis shows the implementation of risk management at a score of 2.5 points in relation to the maximum point of 5.0. Summarising the requirements for the risk management process Australia scores 2.5 points for the process element due to frameworks such as AS/NZS ISO 31000:2018 and COSO I and II, which are implicitly mandatory for public companies. 


\subsection{Consideration of ERM in accounting and reporting}

The basic necessity for the companies' reporting and disclosures are determined by Chapter 2M of the CA. Public companies have to prepare annual financial reports as well as directors' reports [Section 292(1)(b) of the CA; Section 298(1) of the CA]. Another specific requirement is the declaration by the chief executive officer and the chief financial officer that has to be received by the board [Section 295A(1), (2) of the CA], before the board itself can submit its directors' declaration within the financial report [Section 295(4), (5) of the CA]. Here again, it is the CGPR that recommends extending the Chiefs' declaration to the board by stating that the chiefs' opinions are 'formed on the basis of a sound system of risk management and internal control which is operating effectively' (CGPR, Rec. 4.2).

The financial reports also need to comply with the AASB's accounting standards [Section 296(1) of the CA; Section 334 of the CA]. Following the provisions of Section 225(2) of the ASIC Act, the FRC directed the AASB to adopt and transfer the International Financial Accounting Standards (IFRS) into Australian standards, beginning in 2005 (AASB 1057, Basis for Conclusion 2 and 3). Consequently, the current standards are mostly aligned with the international standards, also to the extent of the reporting on risks. To highlight just a few of the risk considerations within the standards, for example, AASB 101, para. 125 requires firms to provide notes on the estimation-uncertainty of assets and liabilities that show a significant risk of future adjustment. Paragraph 30 of AASB 136 on the impairment of assets requires that the uncertainty inherent in an asset needs to be accounted for at the calculation of the asset's value in use. And paragraph $22 \mathrm{~A}$ of AASB 7 instructs a company to disclose on its risk management strategy with regards to the use of financial instruments and the aspects related to hedging therein.

As previously mentioned, in addition to the financial reporting, Australian companies have to disclose a directors' report as a separate statement. For listed companies, the content of this report is generally regulated throughout the sections 298 to 300A of the CA. In terms of risk management, especially the operating and financial review (OFR) required by Section 299A(1) of the CA is relevant. Besides information on the operations, financial position, and business strategies the review is required to entail assessments on the future financial prospects [Section 299A(1) of the CA]. Concretising the CA's provisions, the ASIC's Regulatory Guide (RG) 247 expresses that statements of the OFR, especially on the prospects of future financial years, should not be made without referring on material business risks (ASIC RG 247.61). While the statements should focus only on risks that may affect the financial prospects which are mentioned within the directors' report (ASIC RG 247.62), the risks should nonetheless be described in more detail, while it should also be specified how these risks are managed (ASIC RG 247.64). Supplementary mentioned are disclosures on material economic, environmental, and social sustainability risks (ASIC RG 247.63).

The ASX's Corporate Governance Council confirms these views and once more makes additional recommendations (CGPR, Rec. 7.4). In line with the structural adjustments discussed, Principal 7 outlines that if there is a dedicated risk management committee the board should disclose information on its members, its charter, and its meetings [CGPR, Rec. 7.1(a)(3) to (5)]. If a company, after all, does not have a dedicated committee, the CGPR recommends to, at least, state this fact and explain how the risk framework is monitored otherwise [CGPR, Rec. 7.1(b)]. In addition to that, the company should give information on its internal audit function and the structure thereof, where 
again the absence of such a function should be explained too (CGPR, Rec. 7.3). Finally, the company should disclose on the annual review of the used risk management framework (CGPR, Rec. 7.2).

From a comparative viewpoint, all in all, the required and recommended disclosures of Australian firms show certain similarities to the US as well as to the German reporting requirements. The directors' declaration has clear commonalities with the certification required by Section 302(a) of the SOX, while the directors' declaration definitely has similarities to the German management report. Apart from that, it is again the ASX with its implicit mandatory standards that mainly provides regulation with respect to disclosures on risk management.

Overall, the Australian financial reporting is regulated by the AASB's standards under the oversight of the FRC. The standards are aligned with the IFRS and tend towards a management approach. The risk management accounting gained a score of 0.5 points for the AASB: mainly rebadged international standards which in multiple cases require risk considerations and related statements. Moreover, additional to the AASB requirements, ERM reporting is strongly recommended by the CGPR (Rec. 7), and the ASIC (RG 247); thus, risk management reporting scored 1.5 points.

\subsection{Consideration of ERM in the external corporate monitoring system}

Similar to any other of the observed countries, the annual financial reports of Australian companies have to be audited [Section 301(1) of the CA]. The auditors themselves have to be registered and are supervised by the ASIC (Section 1279, 1287A, 1289A, and 1290 of the CA). Further, they have to follow the rules set by the Australian Auditing Standards (ASA) published by the AUASB [Section 307A (1) of the CA; Section 336 of the CA]. Again, these standards are aimed to be aligned with their international model, the standards of the International Auditing and Assurance Standards Board (IAASB), as required by Section 225(2A) of the ASIC Act, and directed by the FRC (2005). Within the standards, particularly ASA 315 is a good example of the risk-oriented approach that the auditing procedure entails. Besides highlighting the importance of the internal control procedures of the audited firm (ASA 315, para. A49 to A117), this standard also reflects on the audit of the firm's business risks and the internal management thereof (ASA 315, para. A36 to A41, A87). The companies' internal control and risk management structures and processes, therefore, play a major role in the auditing process.

Concerning the firms' statements on risk management not included in the financial reporting, it is ASA 720 that requires the auditor to read these statements and identify inconsistencies with the respective financial report (ASA 720, para. 11). This includes, among other things, the risk management information made within the directors' report or other 'internal control and risk assessment reports' (ASA 720, para. A3). If inconsistencies appear to the auditor, he has to inform the management about this fact (ASA 720, para. 16, 17) and where necessary, take further steps such as to update his understanding of the audited firm (ASA 720, para. 20), or to inform others [ASA 720, para. 19(b)]. Compared to the full audit requirements for the German management report, this approach may be less investigative but it shows that all risk management related publications are subject to the audit process.

Finally, the ASIC has strong oversight powers not only in terms of the auditors but in terms of the disclosing entities as well. Generally, if the annual and half-year reports are 
not submitted to the ASX (ASIC RG 28.3 to RG 28.4), they have to be lodged with the ASIC (Part 2m.3, Division 5 of the ASIC Act). Furthermore, the ASIC may undertake investigations where it thinks it is appropriate, in order to control for suspected contraventions against the corporate law [Section 13(1) of the ASIC Act]. Among other things, this may include the inspection of audit relevant information (Part 3, Division 3 of the ASIC Act), and the inspection of audit deficiencies (Part 3, Division 5 of the ASIC Act). Thus, the investigations may as well extend to any information made on risk management matters and the related audit procedures.

Summarising, and seen from a comparative perspective, Australian federal law, similar to its international counterparts, becomes substantiated through standards and soft laws, brought in place by specialised institutions or governmental agencies. Notable to this strategy repeatedly found in regulatory practice, is the obvious expectation that regulation and enforcement by agencies is superior to a more liberal market that in cases of misbehaviour and expropriation relies on jurisdiction. Given the areas and subjects observed to be regulated by agencies, in theory, this approach may be explained by the expertise of these institutions on the related topics and the inherent complexity of the topics.

The external corporate monitoring system consists of an external audit and the enforcement of auditors and of financial reporting. In Australia, the risk-oriented audit approach is the basis of the external audit. Furthermore, the enforcement of auditors follows auditing standards published by the AUASB. The results of the inspections of audit firms are published by the ASIC (2014). Therefore, the overall external corporate monitoring system is particularly strong in Australia. Since the external auditing is mandatory, full scoring of 1.0 point is justified within this section.

\section{Discussion of the results}

Table 1 shows the results of the multi-country comparison with respect to the main risk management regulations for Australian non-financial listed stock corporations. The table contains brief descriptions for each of the regulatory attributes which are part of the scoring model, the respective character of the regulation, and the allocated scores. The results show that the provisions and guidelines on ERM contribute to higher requirements of regulation found in the US and Australia. While the German regulations are mainly based on hard law, the Australian regulations show an even stronger emphasis on quasi-legal standards than those found within the US. A major impact to the degree of the US risk management regulation can clearly be traced back to the implementation of the SOX, and the resulting requirements with regards to fundamental internal control procedures. In Australia, on the other hand, the provisions given by the ASX heavily influence the overall regulatory approach also leading to increased risk reporting. In both of the overall higher scored countries, the phenomenon of a strong supervisory institution can be observed with the presence of the SEC in the US, and the ASIC in Australia. Both of these institutions may influence standard setting as well as they are responsible for the respective enforcement. 
Regulation of enterprise risk management

Table 1 Comparison of risk management requirements for German, USA, and Australian listed stock corporations

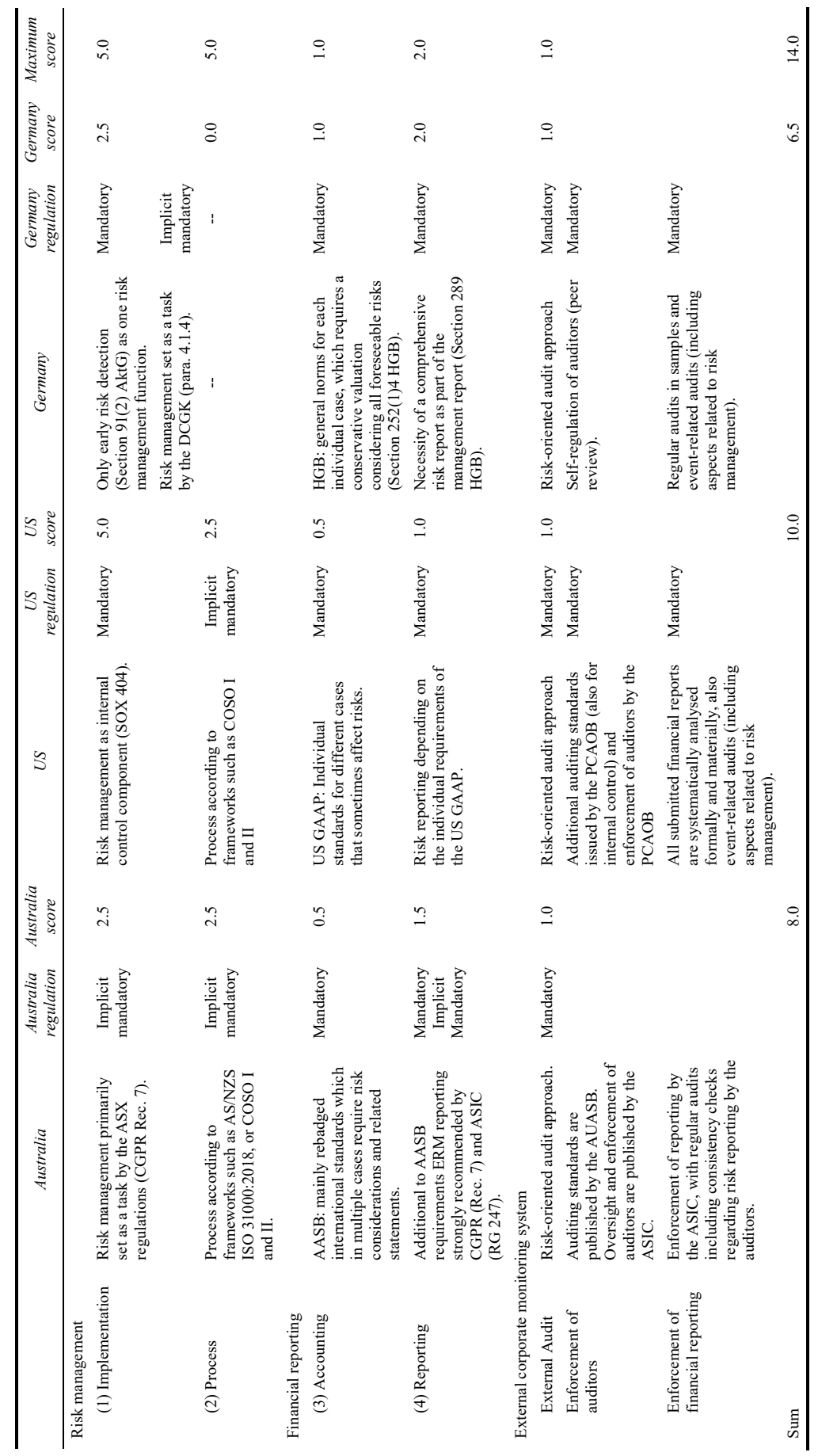


According to the results in Table 1, the US scored the highest, followed by Australia and finally Germany. The main differences in the comparison are as follows:

1 Implementation: the US received a full score of 5.0 due to risk management as an internal control component SOX 404 as mandatory, while Germany and Australia have policies with an external in nature implicit mandatory character.

2 Process: in the US, the risk management process is regulated in the framework COSO I and II in the US (2.5); in Australia in the framework such as AS/NZS ISO 31000:2018 or COSO I and II; Germany does not have any regulation that suggests a special risk management process.

3 Accounting: Germany requires a conservative valuation considering all foreseeable risks [Section 252(1)4 HGB]. On the contrary, US and Australia are based upon multiple case (case-by-case) basis required by standard boards, US GAAP and AASB, respectively.

4 Reporting: all three counties regulated their reporting with a focus on a management approach. In the US, risk report requirements and accounting risk standards are based on a more flexible approach than in Germany and Australia.

5 External corporate monitoring system: the overall external corporate monitoring system of US and Australian listed stock corporations (SEC and ASIC) are strongly regulated relative to the German system, both are quasi-legal in nature.

Having analysed the current regulatory differences in the area of ERM, it has become clear that some of the fundamental country-specific factors have to be taken into account before making recommendations for future regulation. One of these fundamental differences is the common vs. civil law background. When investigating the requirements of regulation, the basic influence of the legal origin should be depicted. In theory, civil law countries (i.e., Germany) may be more likely to be overregulated compared to common law countries (i.e., the US and Australia) due to the rigid nature of civil law legislation that relies on strict codes and procedures (Djankov et al., 2003). In contrast to a possible stronger regulation by codes in the civil law system, the 'fairness' based adjudications of the common law jurisdiction are argued to create a higher level of investor protection (La Porta et al., 2000). Hence, the legal origin may partly be the reason for the larger and more diversified stock markets in the US, and Australia, in contrast to the German capital-market structure which is dominated by banks and large internal shareholders (Chirinko and Elston, 2006; Gorton and Schmid, 2000; La Porta et al., 2000). Building upon this view, increased shareholder diversification also allows for a better sharing of equity related idiosyncratic risks, explaining a higher volatility found among the US firms (Bartram et al., 2012). That is, where shareholders are able to better diversify away idiosyncratic risks, companies are able to invest in riskier projects aiming for faster growth and higher firm value (Bartram et al., 2012). In this case, a stricter regulation of risk management would be more advantageous for common law countries (i.e., Australia) and could explain the different levels of regulation found in Australia's current policy approaches. On the other hand, in a country (i.e., Germany) where control powers are concentrated among only a few creditors, large shareholders, and employee representatives that are part of the supervisory board (Gorton and Schmid, 2000), additional governance regulation including detailed risk management policy may 
arguably be counterproductive. In line with the key assumptions, the US obtained the highest score followed by Australia and Germany.

Apart from these legal-origin considerations, there are other fundamental differences such as overall political-economic orientations of each of the countries (Paridon and Jhagroe, 2009), which lead to different interests of the respective regulators (Sassen, 2014). Since institutional structures vary between the German dual (two-tier) system and the US, and Australian monistic (one-tier) system, the goals and structure of the German social-market-economy approach [DCGK, chapter 1(Foreword)] might not require an identical policy approach as found within a liberal-welfare state such as the US or Australia (Paridon and Jhagroe, 2009). This coherence might particularly become obvious when considering the precautionary principle underlying a number of German policies (Majone, 2010). Overall, these basic differences should be taken into account when making practical recommendations on a country-specific level as well as they have a limiting effect on the precision of general recommendations.

\section{Conclusions}

Regulation has become increasingly a common response to the management of economic issues. Review and scoring of regulation have been central to the research undertaken in this study. The findings show that efficient regulation may largely be dependent on country-specific characteristics, such as the stage of economic development, the origin of the legal system, and the specific provisions affecting corporate governance structures. The characteristics of risk itself generally lead to the conclusion that ERM should preferably be regulated on a liberal basis, allowing the management to react individually and flexible to the ever-changing environments. Our findings have implications for managers, policymakers, theory, and future research.

1 The management needs to be able to make timely decisions on the basis of the individual circumstances. Hence, strict provisions on procedures and fixed company-internal structures should be avoided. Additionally, in order to account for the firm-size differences and the characteristics of risk that varies among different industries, regulation either needs to be highly individualised or leave room for increased self-regulation. Overall, the described peculiarities of risk and risk management therefore often stand in favour of a soft-law approach, under which a company has the chance to decide if it complies or not.

2 Concerning the state of development of the three countries, an effective enforcement and the presence of well-informed regulators can generally be presumed (Djankov et al., 2003). Accordingly, imposing governmental regulation, if by law, or by the implementation of agencies can be seen as a legitimate way to intervene where markets do not create efficiency. Thus, in contrast to leaving ERM related issues up to jurisdiction and repeated litigation, the option of regulatory intervention is likely to be advantageous with respect to the welfare creation process. On the other hand, owing to the dynamic and uncertain nature of risk, the respective regulation should balance and incorporate the required managerial freedom and flexibility.

Having said that ERM regulation should not be too strict but should incorporate a high 'degree of freedom', at the same time the existing guidelines, such as the COSO 
framework, are criticised for their open-end approach and the lack of practical guidance. The COSO mechanisms are widely adopted in the risk management process in the US and Australia. As the use of such frameworks is generally not fully mandatory and companies in many cases have the choice to comply or explain, these arguments do not necessarily contradict each other. Instead, it could be argued that the lack of guidance and technical support from these guidelines is forcing firms to invest in increased external consultation, leading to higher costs of implementation. As a result, the US and Australia risk management regulations rely on the risk management guidelines and framework may lead to firms incurring substantial implementation cost. Without precise provisions, the interpretation of laws and respective practical execution of legal requirements are left to the companies and may lead to uncertainties in terms of how to comply with new regulations. German firms have to implement an ERM but its process is not specified. Therefore, the management has to interpret how the respective risk management processes should be designed.

It has become clear that the differences in international regulation may lead to redundancies in risk management requirements. Particularly, companies listed in more than one country may be faced with overlapping provisions, while the regulations also may lead to conflicting laws. As such provisions lead to higher costs of compliance and reduce the efficiency of capital markets (see for example the decreasing attractiveness of the US stock market for German companies summarised by Happ and Pott (2007), it seems to be recommendable to harmonise the respective international regulations in order to provide multinational corporations with similar requirements across different countries. Where exemptions for multi-listed entities might be a simple solution to avoid redundant ERM systems, instead of converging different regulations and thereby increasing the synergies among the required activities, it may as well help to overcome the problem of redundancies by harmonisation with the consideration of country-specific characteristics. Moreover, multilateral cooperation in harmonising international regulations safeguard against businesses taking unnecessary risks that jeopardise the global financial system.

Furthermore, it might be an option that smaller companies in low-risk industries may currently be faced with inefficient hard laws, and should instead be provided with the option of self-regulation.

3 From a theoretical point of view and based on the reviewed empirical findings, the positive impact of current regulation on the process of economic welfare creation seems to be more likely than not. However, the strict regulations of the SOX have led to a high level of regulation. On the other hand, particularly concerning the US and Australia, unspecific risk-reporting requirements, which contribute to increased liability risks, may promote an inefficient search for accountability and hinder the disclosure of relevant information. Considering the corporate governance background of ERM, the findings do not indicate that the current risk-reporting provisions will contribute to a reduction in the rate of fraud and expropriation by management.

Furthermore, with the uncertainty that is inextricably linked to risk, it may not become evident as to where exactly the advantages of ERM regulation maximally outweigh the disadvantages. To a certain degree, it is therefore, understandable that 
current regulations may largely be a response to a few but extreme cases of human and systematic failure.

4 This study has limitations and some of these may provide an avenue for future research. First, the approach focuses primarily on governance and top-level management considerations. In fact, the approach does not entail aspects specifically relevant to middle and lower management levels. In order to compare the outcome of varying risk management regulation on the efficiency of middle and lower management tasks, further research is required. Second, our study focuses on non-financial companies. Therefore, it is our contention that additional studies across these perspectives and other industries should be integrated. As a result, the fundamental risks may deviate among different industries and the conclusions and recommendations stated may therefore not hold true in each individual case. As such, future research would expand future studies to be applicable in other contexts. Third, while our paper is based on policies and regulations in place during the time of preparation of this study, results may be subject to future changes in the regulations and policies of risk management within the three countries examined. Future research into ERM would benefit from further case studies in other countries to see the interplay between the levels of ERM regulation and its respective economic and legal environment.

\section{References}

Ai, J., Bajtelsmit, V. and Wang, T. (2016) 'The combined effect of enterprise risk management and diversification on property and casualty insurer performance', Journal of Risk and Insurance, Vol. 85, No. 2, pp.513-543.

Arena, M., Arnaboldi, M. and Azzone, G. (2010) 'The organizational dynamics of enterprise risk management', Accounting, Organizations and Society, Vol. 35, No. 7, pp.659-675.

Australian Securities and Investments Commission (ASIC) (2014) Audit Inspection and Surveillance Programs [online] https://asic.gov.au/regulatory-resources/financial-reportingand-audit/auditors/audit-inspection-and-surveillance-programs/ (accessed 5 April 2018).

Barton, T.L., Shenkir, W.G. and Walker, P.L. (2002) Making Enterprise Risk Management Pay Off, Prentice Hall, Upper Saddle River, NJ.

Bartram, S., Brown, G and Stulz, R.M. (2012) 'Why are U.S. stocks more volatile?', Journal of Finance, Vol. 67, No. 4, pp.1329-1370.

Baxter, R., Bedard, J.C., Hoitash, R. and Yezegel, A. (2013) 'Enterprise risk management program quality. Determinants, value relevance, and the financial crisis', Contemporary Accounting Research, Vol. 30, No. 4, pp.1264-1295.

Beasley, M.S., Pagach, D.P. and Warr, R.S. (2008) 'Information conveyed in hiring announcements of senior executives overseeing enterprise-wide risk management processes', Journal of Accounting, Auditing and Finance, Vol. 23, pp.311-332, doi:10.2139/ssrn.916783.

Bohnert, A., Gatzert, N., Hoyt, R.E. and Lechner, P. (2019) 'The drivers and value of enterprise risk management: evidence from ERM ratings', The European Journal of Finance, Vol. 25, No. 3, pp.234-255.

Booth, P. (1997) 'The political economy of regulation', British Actuarial Journal, Vol. 3, No. 3, pp.675-707.

Bromiley, P., Mcshane, M.K., Nair, A. and Rustambekov, E. (2015) 'Enterprise risk management: review, critique, and research directions', Long Range Planning, Vol. 48, No. 4, pp.265-276. 
CAS (2003) The CAS Enterprise Risk Management Committee Casualty Actuarial Society Forum Summer 2003, pp.99-164 [online] https://www.casact.org/pubs/forum/03sforum/03sf099.pdf (accessed 6 August 2018).

Chirinko, R.S. and Elston, J.A. (2006) 'Finance, control and profitability. the influence of German banks', Journal of Economic Behavior and Organization, Vol. 59, No. 1, pp.69-88.

Choi, Y., Ye, X., Zhao, L. and Luo, A.C. (2015) 'Optimizing enterprise risk management. A literature review and critical analysis of the work of Wu and Olson', Annals of Operations Research, Vol. 237, Nos. 1-2, pp.281-300.

Coglianese, C. and Lazer, D. (2003) 'Management-based regulation. Prescribing private management to achieve public goals', Law and Society Review, Vol. 37, No. 4, pp.691-730.

COSO (1992) Committee of Sponsoring Organizations of the Treadway Commission, Internal Control - Integrated Framework, Jersey City/New Jersey.

COSO (2004) Committee of Sponsoring Organizations of the Treadway Commission/PricewaterhouseCoopers, Enterprise Risk Management - Integrated Framework, Executive Summary, Jersey City/New Jersey.

COSO (2017) Committee of Sponsoring Organizations of the Treadway Commission: Enterprise Risk Management - Integrating with Strategy and Performance, Executive Summary, Jersey City/New Jersey.

D'Arcy, S. and Brogan, J.C. (2001) 'Enterprise risk management', Journal of Risk Management of Korea, Vol. 12, No. 1, pp.207-228.

Dahringer, L.D. and Mühlbacher, H. (1991) International Marketing: A Global Perspective, Addison-Wesley Publishing Company, Cengage Learning EMEA.

Demidenko, E. and McNutt, P. (2010) 'The ethics of enterprise risk management as a key component of corporate governance', International Journal of Social Economics, Vol. 37, No. 10 , pp.802-815.

Desender, K.A. and Lafuente, E. (2012) 'The role of enterprise risk management in determining audit fees. Complement or substitute', in Jalilvand, A. and Malliaris, A.G. (Eds.): Risk Management and Corporate Governance, Routledge, New York/London.

Dias, A. (2017) 'A more effective audit after COSO ERM 2017 or after ISO 31000: 2009?', Revista Perspectiva Empresarial, Vol. 4, No. 2, pp.73-82, ISSN: 2389-8194 (En línea).

Djankov, S., Glaeser, E., La Porta, R., Lopez-de-Silanes, F. and Shleifer, A. (2003) 'The new comparative economics', Journal of Comparative Economics, Vol. 31, No. 4, pp.595-619.

Dornberger, K., Oberlehner, S. and Zadrazil, N. (2014) 'Challenges in implementing enterprise risk management', Journal of Finance and Risk Perspectives, Vol. 3, No. 3, pp.1-14.

Duffie, D. (2017) 'Financial regulatory reform after the crisis: an assessment', Management Science, Vol. 64, No. 10, pp.4471-4965.

Eckles, D.L., Hoyt, R.E. and Miller, S.M. (2014) 'The impact of enterprise risk management on the marginal cost of reducing risk: evidence from the insurance industry,' Journal of Banking and Finance, Vol. 49, pp.409-423, doi:10.1016/j.jbankfin.2014.10.006.

Farrell, M. and Gallagher, R. (2015) 'The valuation implications of enterprise risk management maturity', Journal of Risk and Insurance, Vol. 82, No. 3, pp.625-657.

Fraser, J.R., Fraser, J. and Simkins, B. (2010) 'Enterprise Risk Management: Today's Leading Research and Best Practices for Tomorrow's Executives, Vol. 3, John Wiley \& Sons, Hoboken, New Jersey.

FRC (2005) Financial Reporting Council, AUASB Strategic Direction as of 6th April 2005 [online] http://www.auasb.gov.au/admin/file/content2/c7/AUASB_Strategic_Direction_April_ 2005.pdf (accessed 15 January 2016). 
Freidank, C.C. and Sassen, R. (2012) 'Regulierungstheoretischer ansatz des controllings. Notwendigkeit einer weiterentwicklung von unternehmensführung und-überwachung', in Freidank, C-C. and Velte, P. (Eds.): Corporate Governance, Abschlussprü̈ung und Compliance, pp.161-189, Neue Entwicklungen aus Nationaler und Internationaler Sicht, Berlin.

Glenn, H.P. (2006) 'Aims of comparative law', Elgar Encyclopaedia of Comparative Law, Vol. 57, Edward Elgar Publishing, Cheltenham, UK.

Gorton, G. and Schmid, FA. (2000) 'Universal banking and the performance of German firms', Journal of Financial Economics, Vol. 58, Nos. 1-2, pp.29-80.

Grace, M.F., Leverty, J.T., Phillips, R.D. and Shimpi, P. (2015) 'The value of investing in enterprise risk management', Journal of Risk and Insurance, Vol. 82, No. 2, pp.289-316.

Haji-Togok, S., Isa, C.R. and Zainuddin, S. (2014) 'Review of enterprise risk management (ERM) literature', Conference Paper International Conference on Technology and Business Management, pp.36-48.

Happ, D. and Pott, C. (2007) 'Auswirkungen des Sarbanes-Oxley Act Section 404: kosten und nutzen für europäische unternehmen', Zeitschrift Für Internationale und Kapitalmarktorientierte Rechnungslegung, pp.666-672.

Hart, O. (2009) 'Regulation and Sarbanes-Oxley', Journal of Accounting Research, Vol. 47, No. 2, pp.437-445.

Hayne, C. and Free, C. (2014) 'Hybridized professional groups and institutional work. COSO and the rise of enterprise risk management', Accounting, Organizations and Society, Vol. 39, No. 5, pp.309-330.

Heathcote, P. (2003) 'Does the Australian Stock Exchange's monopoly over securities markets maintain, facilitate and improve the performance of the Australian financial system', Australian Journal of Corporate Law, Vol. 15, pp.279-285.

Hertog, J. (2010) 'Review of economic theories of regulation', Utrecht University Discussion Paper Series, Vols. 10, No. 18, pp.1-59.

Highley, S. (2016) ANAO Risk Management Framework 2017-18 [online] https://www.anao. gov.au/work/corporate/anao-risk-management-framework-2016-17 (accessed 6 August 2018).

Hoyt, R.E. and Liebenberg, A.P. (2003) 'The determinants of enterprise risk management. Evidence from the appointment of chief risk officers', Risk Management Insurance Review, Vol. 6, No. 1, pp.37-52.

Hoyt, R.E. and Liebenberg, A.P. (2006) The Value of Enterprise Risk Management: Evidence from the US. Insurance Industry, Working Paper, University of Georgia.

Hoyt, R.E. and Liebenberg, A.P. (2011) 'The value of enterprise risk management', Journal of Risk and Insurance, Vol. 78, No. 4, pp.795-822.

Huber, G.P. (1974) 'Multi-attribute utility models. a review of field and field-like studies', Management Science, Vol. 20, No. 10, pp.1393-1402.

Jensen, M.C. and Meckling, W.H. (1976) 'Theory of the firm. Managerial behavior, agency costs and ownership structure', Journal of Financial Economics, Vol. 3, No. 4, pp.305-360.

Kang, H., Cheng, M. and Gray, S.J. (2007) 'Corporate governance and board composition. Diversity and independence of Australian boards', Corporate Governance: An International Review, Vol. 15, No. 2, pp.194-207.

Kayastha, P., Dhital, M.R. and De Smedt, F. (2013) 'Application of the analytical hierarchy process (AHP) for landslide susceptibility mapping: a case study from the Tinau watershed, west Nepal', Computers \& Geosciences, Vol. 52, pp.398-408 [online] https://doi.org/10.1016/ j.cageo.2012.11.003.

Keeney, R.L. and Raiffa, H. (1993) 'Decisions with multiple objectives', Preferences and Value Tradeoffs, DOI: 10.1017/cbo9781139174084.005. 
Kehoe, J. (2018) Former ANZ Executive says Widespread Risk Failures could Lead to Downturn [online] https://www.afr.com/business/banking-and-finance/bank-veteran-frets-over-lax-riskcontrols-20181021-h16x3z (accessed 21 January 2019).

Khan, M.J., Hussain, D. and Mehmood, W. (2016) 'Why do firms adopt enterprise risk management (ERM)? Empirical evidence from France', Management Decision, Vol. 54, No. 8, pp.1886-1907.

Khanna, T., Kogan, J. and Palepu, K. (2006) 'Globalization and similarities in corporate governance: a cross-country analysis', Review of Economics and Statistics, Vol. 88, No. 1, pp.69-90.

Kleffner, A.E., Lee, R.B. and McGannon, B. (2003) 'The effect of corporate governance on the use of enterprise risk management: evidence from Canada', Risk Management and Insurance Review, Vol. 6, No. 1, pp.53-73.

Kraus, V. and Lehner, O.M. (2012) 'The Nexus of enterprise risk management and value creation. A systematic literature review', ACRN Journal of Finance and Risk Perspectives, Vol. 1, No. 1, pp.91-163.

La Porta, R., Lopez-de-Silanes, F., Shleifer, A. and Vishny, R.W. (2000) 'Investor protection and corporate governance', Journal of Financial Economics, Vol. 58, Nos. 1-2, pp.3-27.

Larsson, M. and Söderberg, G. (2017) 'Banking development, the global financial crisis and the basel regulations: 1995-2015', in Finance and the Welfare State, pp.123-133, Palgrave Macmillan, Cham.

Lechner, P. and Gatzert, N. (2018) 'Determinants and value of enterprise risk management: empirical evidence from Germany', The European Journal of Finance, Vol. 24, No. 10, pp.867-887.

Levy, J.B. and Yoon, E. (2001) 'Methods of country risk assessment for international market-entry decision', in Getting Better at Sensemaking, pp.287-323, Emerald Group Publishing Limited, DOI:10.1016/S1069-0964(00)09010-4.

Lowry, J. (2012) 'The irreducible core of the duty of care, skill and diligence of company directors. Australian securities and investments commission v Healey', Modern Law Review, Voll. 75, No. 2, pp.249-261.

Majone, G. (1994) 'The rise of the regulatory state in Europe', West European Politics, Vol. 17, No. 3, pp.77-101.

Majone, G. (2010) 'Strategic issues in risk regulation and risk management', Risk and Regulatory Policy OECD Reviews of Regulatory Reform, DOI: 10.1787/9789264082939-7-en.

McShane, M. (2018) 'Enterprise risk management: history and a design science proposal', The Journal of Risk Finance, Vol. 19, No. 2, pp.137-153.

McShane, M.K., Nair, A. and Rustambekov, E. (2011) 'Does enterprise risk management increase firm value', Journal of Accounting, Auditing and Finance, Vol. 26, No. 4, pp.641-658.

Mikes, A. (2009) 'Risk management and calculative cultures', Management Accounting Research, Vol. 20, No. 1, pp.18-40

Müller-Berghoff, B. (1984) 'Die eigene exportindustxie stiker forden', Blick Durch die Wirtschaft, 3 February, pp.3-4.

Narine Weldon, M. (2017) 'Corporate governance, compliance, social responsibility, and enterprise risk management in the trump/pence era', The Tennessee Journal of Business Law, Vol. 19, No. 1, pp.275-305.

Ndedi, A. and Kingsly, M. (2015) Rethinking the Building Blocks of the Enterprise Risk Management Model, 13 May [online] https://ssrn.com/abstract=2605817 or http://dx.doi.org/ 10.2139/ssrn.2605817.

Nessen, P. (1999) 'The Americanization of Australian corporate law', Syracuse Journal of International Law and Commerce, Spring, Vol. 26, No. 2, pp.239-266.

Nguyen, T. and Molinari, RD. (2009) 'Versicherungsaufsicht in Deutschland. Zur notwendigkeit der versicherungsregulierung in der marktwirtschaft', Schriften der Wisschenschaftlichen Hochschule Lahr, pp.1-70. 
Nocco, B.W. and Stulz, R.M. (2006) 'Enterprise risk management. Theory and practice', Journal of Applied Corporate Finance, Vol. 18, No. 4, pp.8-20.

Nölke, A. (2010) 'The politics of accounting regulation: responses to the subprime crisis', in Global Finance in Crisis, pp.51-69, Routledge.

Omarova, S.T. (2015) 'One step forward, two steps back? The institutional structure of US Financial Services regulation after the crisis of 2008', in Huang, R.H. and Schoenmaker, D. (Eds.): Institutional Structure of Financial Regulation: Theories and International Experiences, Cornell Legal Studies Research Paper No. 16-2, 17 November [online] https://ssrn.com/abstract=2692234 (accessed 23 December 2017).

Paape, L. and Speklé, R.F. (2012) 'The adoption and design of enterprise risk management practices. An empirical study', European Accounting Review, Vol. 21, No. 3, pp.533-564.

Pagach, D.P. and Warr, R.S. (2010) The Effects of Enterprise Risk Management on Firm Performance, DOI: 10.2139/ssrn.1155218.

Pagach, D.P. and Warr, R.S. (2011) 'The characteristics of firms that hire chief risk officers', Journal of Risk and Insurance, Vol. 78, No. 1, pp.185-211.

Paridon, K. and Jhagroe, S. (2009) 'Reduction of compliance costs. An international perspective', in Nijsen, A., Hudson, J., Mueller, C., Paridon, K. and Thurik, R. (Eds.): Business Regulation and Public Policy, The Costs and Benefits of Compliance, pp.11-25, Springer, New York.

Peltzman, S. (1976) 'Toward a more general theory of regulation', Journal of Law and Economics, Vol. 19, No. 2, pp.211-240.

Peltzman, S., Levine, M.E. and Noll, R.G. (1989) 'The economic theory of regulation after a decade of deregulation', in Brookings Papers on Economic Activity, Microeconomics, pp.1-59.

Pickvance, C. (2005) 'The four varieties of comparative analysis: the case of environmental regulation', Journal of Housing and the Built Environment, Vol. 16, No. 1, pp.7-28.

Posner, R.A. (1974) 'Theories of economic regulation', in Bell Journal of Economics and Management Science, Vol. 5, No. 2, pp.335-358.

Power, M. (2004a) 'The nature of risk: the risk management of everything', Balance Sheet, Vol. 12, No. 5, pp.19-28.

Power, M. (2004b) 'The risk management of everything', Journal of Risk Finance, Vol. 5, No. 3, pp.58-65.

Purdy, G. (2010) 'ISO 31000:2009. Setting a new standard for risk management', Risk Analysis, Vol. 30, No. 6, pp.881-886.

Sassen, R. (2014) 'Comparison of risk management regulation from a corporate governance perspective within the German and United States legal area', Journal of Governance and Regulation, Vol. 3, No. 4, pp.138-148.

Sassen, R., Hinze, A.K. and Hardeck, I. (2016) 'Impact of ESG factors on firm risk in Europe', Journal of Business Economics, Vol. 86, No. 8, pp.867-904.

Shanmuganathan, M. (2018) 'Corporate governance relationship with strategic management: a longitudinal case analysis of RELX Group (Elsevier)', International Journal of Comparative Management, Vol. 1, No. 3, pp.273-294.

Shleifer, A. (2005) 'Understanding regulation', European Financial Management, Vol. 11, No. 4, pp.439-451.

Shleifer, A. (2010) Efficient Regulation, in National Bureau of Economic Research Working Paper Series Working Paper No. 15651, pp.1-27.

Shleifer, A. and Vishny, R.W. (1997) 'A survey of corporate governance', in Journal of Finance, Vol. 52, pp.737-783.

Simmons, O.S. (2013) 'The corporate immune system. Governance from the inside out', in University of Illinois Law Review, No. 3, pp.1131-1170.

SRA (2015) Foundations of Risk Analysis, Discussion Document [online] http://www.sra.com/ resources (accessed 6 June 2018). 
Stigler, G.J. (1971) 'The theory of economic regulation', Bell Journal of Economics and Management Science, Vol. 2, No. 1, pp.3-21.

Tekathen, M. and Dechow, N. (2013) 'Enterprise risk management and continuous re-alignment in the pursuit of accountability: a German case', Management Accounting Research, Vol. 24, No. 2, pp.100-121.

Tomasic, R. (2006) 'The modernisation of corporations law. Corporate law reform in Australia and beyond', Australian Journal of Corporate Law, Vol. 19, No. 1, pp.2-34.

Warin, T. and Sanger, W. (2018) 'Connectivity and closeness among international financial institutions: a network theory perspective', International Journal of Comparative Management, Vol. 1, No. 3, pp.225-254.

Yoshikawa, T. and Rasheed, A.A. (2009) 'Convergence of corporate governance: critical review and future directions', Corporate Governance: An International Review, Vol. 17, No. 3, pp.388-404.

Zangemeister, C. (2014) 'Nutzwertanalyse in der systemtechnik', Eine Methodik zur Multidimensionalen Bewertung und Auswertung von Projektalternativen, 5th ed., Books on Demand, Norderstedt. 